\title{
KONTRIBUSI TEKNOLOGI INFORMASI DAN KOMUNIKASI TERHADAP PENINGKATAN NILAI TAMBAH SEKTOR PARIWISATA DI JAWA TENGAH
}

\author{
Dyah Makutaning Dewi ${ }^{1}$, Ika Yuni Wulansari ${ }^{2}$ \\ ${ }^{1}$ Mahasiswi Politeknik Statistika STIS Jakarta; ${ }^{2}$ Dosen Politeknik Statistika STIS Jakarta \\ ${ }^{1} 16.9096 @$ stis.ac.id; 2ikayuni@stis.ac.id
}

Diterima: Februari 2020; Direvisi: April 2020; Disetujui: April 2020

\begin{abstract}
Indonesia is one of the countries with rapid development of information and communication technology (ICT). The rapid development of ICT can encourage tourism sector, one of them in the province of Central Java. However, on the year 2018 there are several districts or cities that experienced negative relation between internet users rate and value added of tourism sector of 48,57\% of several districts in the Province of Central Java. This research aims to provide an overview of the conditions of tourism sector and the percentage of internet users in Central Java and know the influence of ICT on increasing the value added of tourism sector in Central Java in 2015-2018. This research used panel data from Statistics Indonesia and Department of Youth, Sports and Tourism Central Java. The results show that the percentage of internet users, the number of workers in tourism business, and capital expenditure have positive and significant impact to the value added of tourism sector in Central Java. Therefore, the value added of tourism sector needs to be supported by increased promotion via Internet. In addition, the Government's role is required in allocating capital for tourism sector development.
\end{abstract}

\section{Keyword: tourism, panel data regression, ICT}

\begin{abstract}
Abstraksi. Indonesia merupakan salah satu negara yang mengalami perkembangan Teknologi Informasi dan Komunikasi (TIK) yang pesat. Adanya perkembangan TIK yang pesat diharapkan dapat mendorong sektor pariwisata, salah satunya di Provinsi Jawa Tengah. Namun, pada tahun 2018 terdapat beberapa kabupaten atau kota yang memiliki hubungan negatif antara persentase pengguna internet dengan nilai tambah sektor pariwisata yaitu sebesar 48,57\% dari jumlah kabupaten atau kota di Provinsi Jawa Tengah. Penelitian ini bertujuan untuk memberikan gambaran kondisi sektor pariwisata dan persentase pengguna internet di Jawa Tengah dan mengetahui pengaruh TIK terhadap peningkatan nilai tambah sektor pariwisata di Jawa Tengah tahun 2015-2018. Penelitian ini menggunakan data panel dari Badan Pusat Statistik (BPS) dan Dinas Kepemudaan, Olahraga, dan Pariwisata (Disporapar) Jawa Tengah. Hasil analisis menunjukkan bahwa persentase pengguna internet, jumlah tenaga kerja di usaha pariwisata, dan belanja modal berpengaruh positif dan signifikan terhadap nilai tambah sektor pariwisata di Jawa Tengah. Oleh karena itu, peningkatan nilai tambah sektor pariwisata perlu ditunjang oleh peningkatan promosi melalui internet. Selain itu, diperlukan peran Pemerintah dalam mengalokasikan modal untuk perkembangan sektor pariwisata.
\end{abstract}

Kata kunci: pariwisata, regresi data panel, TIK

\section{PENDAHULUAN}

Dewasa ini pariwisata menjadi bagian yang tak terpisahkan bagi sebagian besar masyarakat. Pariwisata menjadi salah satu industri yang telah berkembang di Indonesia yang dapat dilihat dari salah 
satunya melalui jumlah kunjungan mancanegara di Indonesia. Berdasarkan data Kementerian Pariwisata (Kemenpar), pada September 2019 kunjungan wisatawan mancanegara (wisman) ke Indonesia melalui seluruh pintu masuk berjumlah 1.388.719 kunjungan. Angka tersebut mengalami peningkatan sebesar $1,30 \%$ dibandingkan periode yang sama pada September tahun lalu yang berjumlah 1.370.943 kunjungan. Jika dilihat dari kebangsaan, pada September 2019 jumlah kunjungan wisman tertinggi yaitu Malaysia yang berjumlah 229.173 kunjungan, Tiongkok yang berjumlah 172.856 kunjungan, Singapura yang berjumlah 159.215 kunjungan, Australia yang berjumlah 138.554 kunjungan, dan Timor Leste yang berjumlah 97.603 kunjungan.

Berdasarkan data di atas menunjukkan bahwa pariwisata dapat dijadikan prioritas dalam pembangunan ekonomi di Indonesia. Lebih lanjutnya lagi, menurut Kemenpar (2015) sebagai industri jasa, sektor pariwisata telah memberikan kontribusi dan peran strategis dalam pembangunan perekonomian nasional dan peningkatan kesejahteraan masyarakat melalui kontribusi terhadap Produk Domestik Bruto (PDB).

Menurut World Travel \& Tourism Council (WTTC), pariwisata merupakan aktivitas yang penting di seluruh dunia. Hal tersebut disebabkan pariwisata memiliki dampak langsung dan tidak langsung dalam perekonomian. Kontribusi langsung sektor pariwisata di dalam PDB dapat dihitung dari output karakteristik pariwisata yang terdapat di national accounting seperti hotel, maskapai penerbangan, agen perjalanan, dan pelayanan rekreasi yang berhubungan langsung dengan wisatawan.

Jawa Tengah merupakan salah satu provinsi di Indonesia yang memiliki potensi pariwisata yang besar. Berdasarkan data Dinas Kepemudaan, Olahraga, dan Pariwisata (Disporapar) Jawa Tengah, pada tahun 2018 Jawa Tengah memiliki daya tarik wisata sebanyak 692 dengan rincian 240 jenis alam, 132 jenis budaya, 199 jenis buatan, 43 jenis minat khusus dan 78 lainlain. Pada tahun yang sama, jumlah wisatawan sebanyak 49.620 .775 orang wisatawan dengan rincian 677.168 orang wisatawan mancanegara dan 48.493.607 orang wisatawan nusantara. Kemudian dalam hal akomodasi memiliki 291 hotel bintang, 1.130 hotel non bintang, serta jumlah home stay sebanyak 765 .

Selain itu, Provinsi Jawa Tengah memiliki Biro Perjalanan Wisata (BPW) sebanyak 211 usaha dan Agen Perjalanan Wisata (APW) sebanyak 313 agen. Jumlah restoran sebanyak 294 usaha dan rumah makan sebanyak 1.588 usaha.

Didukung juga pada tahun 2019 Provinsi Jawa Tengah mendapatkan penghargaan Indonesia's Attractiveness Award 2019. Pada penghargaan tersebut Provinsi Jawa Tengah memperoleh gold pada kategori sektor pariwisata skala provinsi besar (Syarifah, 2019). Selain itu, Provinsi Jawa Tengah mendapatkan penghargaan Indonesia Muslim Travel Index (IMTI) 2019 sebagai destinasi wisata halal unggulan (Pemerintah Provinsi Jawa Tengah, 2019).

Pada tahun 2015 hingga 2018 kontribusi sektor pariwisata di Provinsi Jawa Tengah yang diproksikan dengan sektor penyediaan akomodasi dan makan minum terhadap PDRB terus mengalami peningkatan. Pada tahun 2018, sektor tersebut berkontribusi terhadap PDRB sebesar 3,26\%. Pada tahun sebelumnya sektor tersebut berkontribusi sebesar 3,17\%.

Adanya pertumbuhan pariwisata di Provinsi Jawa Tengah yang berperan dalam 
kondisi perekonomian di provinsi tersebut pastinya tidak terlepas dari beberapa faktor.

Mankiw (2010) menjelaskan bahwa output yang berupa barang dan jasa yang terdapat di PDB didasarkan pada faktor produksi. Faktor produksi yang berperan penting dalam menciptakan output yaitu modal, tenaga kerja, dan teknologi.

Dalam hal akumulasi modal misalnya belanja modal yang dilakukan oleh kabupaten atau kota di suatu provinsi. Belanja modal merupakan pengeluaran yang digunakan dalam pembelian/pengadaan atau pembangunan aset tetap yang berwujud yang nilai manfaatnya lebih dari satu tahun. Pembentukan aset tersebut dapat meliputi alat-alat komunikasi, alat-alat ukur, konstruksi jalan, penerangan jalan, instalasi listrik dan telepon, dan sebagainya (BPS, 2017).

Selain itu, sektor pariwisata di Provinsi Jawa Tengah berkontribusi dalam penciptaan lapangan kerja. Misalnya pada tahun 2018 Kabupaten Semarang memiliki jumlah tenaga kerja yang bekerja di usaha pariwisata sebanyak 5.548 jiwa. Kemudian, Kabupaten Klaten memiliki jumlah tenaga kerja yang bekerja di usaha pariwisata sebanyak 3.191 jiwa.

Selain itu, sektor pariwisata pun tidak terlepas dari peran teknologi. Menurut Susanta (2016) perkembangan Teknologi Informasi dan Komunikasi (TIK) dapat mendorong pertumbuhan industri pariwisata dengan menyebarkan informasi suatu destinasi melalui media sosial. Hal tersebut juga didukung dengan pernyataan Todaro dan Smith (2003) yaitu perkembangan teknologi merupakan sumber pertumbuhan ekonomi yang paling penting.

Pada tahun 2017, Indeks Pembangunan Teknologi Informasi dan Komunikasi (IPTIK) di Provinsi Jawa Tengah sebesar 4,72. Angka tersebut meningkat dibandingkan tahun 2016 yang sebesar 4,08 dan tahun 2015 sebesar 3,63.

Tabel 1.

Sepuluh Kabupaten atau Kota di Jawa Tengah dengan Persentase Pengguna Internet

Tertinggi Tahun 2018

\begin{tabular}{lcc}
\hline \multicolumn{1}{c}{ Kabupaten atau Kota } & $\begin{array}{c}\text { Peringkat Persentase } \\
\text { Pengguna Internet }\end{array}$ & $\begin{array}{c}\text { Peringkat Nilai Tambah } \\
\text { Sektor Pariwisata }\end{array}$ \\
\hline Kota Semarang & 1 & 1 \\
Kabupaten Sukoharjo & 2 & 12 \\
Kota Surakarta & 3 & 2 \\
Kabupaten Banyumas & 4 & 4 \\
Kabupaten Semarang & 5 & 7 \\
Kabupaten Klaten & 6 & 9 \\
Kabupaten Karanganyar & 7 & 18 \\
Kabupaten Cilacap & 8 & 10 \\
Kabupaten Kudus & 9 & 19 \\
Kabupaten Jepara & 10 & 14 \\
\hline
\end{tabular}

Sumber: Badan Pusat Statistik, 2018 (diolah) 
Pada Tabel 1 ditunjukkan kabupaten atau kota di Jawa Tengah yang menduduki peringkat sepuluh besar persentase pengguna internet. Pada tabel tersebut ditunjukkan bahwa terdapat kabupaten atau kota yang memiliki peringkat persentase pengguna internet yang berbanding lurus dengan peringkat nilai tambah sektor pariwisata yang dimiliki, misalnya adalah Kota Semarang, Kota Surakarta, Kabupaten Banyumas, Kabupaten Semarang, Kabupaten Klaten, Kabupaten Cilacap, dan Kabupaten Jepara. Akan tetapi, terdapat pula beberapa kabupaten atau kota yang memiliki peringkat persentase pengguna internet yang tidak berbanding lurus dengan peringkat nilai tambah sektor pariwisata yang dimiliki, misalnya adalah Kabupaten Sukoharjo, Kabupaten Karanganyar, dan Kabupaten Kudus. Apabila dilihat dari keseluruhan, terdapat sebesar 48,57\% kabupaten atau kota yang memiliki peringkat persentase pengguna internet yang tidak berbanding lurus dengan peringkat nilai tambah sektor pariwisata yang dimiliki.

Susanta (2016) menjelaskan bahwa internet telah meningkatkan kemudahan dalam melakukan pemesanan tiket perjalanan dan akomodasi sehingga membuat kemudahan dan kenyamanan dalam perjalanan. Mihalic dan Buhalis (2013) menjelaskan bahwa internet telah menerima perhatian dari pengusaha, eksekutif, investor, dan pengamat bisnis telah mengasumsikan bahwa internet mengubah segalanya dalam hal perusahaan dan persaingan. Adapun citra destinasi merupakan kumpulan kepercayaan dan kesan terhadap destinasi yang diperoleh informasi dari berbagai sumber (Zhang et al, 2014). Oleh karena itu, informasi mengenai destinasi dapat menentukan keputusan pemilihan destinasi (Baloglu \& McCleary, 1999; Echtner \& Ritchie, 1991).

Selain itu, penggunaan teknologi modern seperti penggunaan internet secara signifikan berpengaruh dalam meningkatkan sektor pariwisata (Jonathan dan Tarigan, 2016; Ilić dan Nikolić, 2018). Namun dalam penggunaan teknologi modern di dalam sektor pariwisata perlu modal atau infrastruktur yang mendukung. Investasi dalam teknologi digital mempunyai efek yang positif sehingga sektor pariwisata menjadi kompetitif (Bekteshi dan Bekteshi, 2017). Berkembangnya sektor pariwisata dapat mendorong pemerintah lokal dalam menyediakan infrastruktur sehingga meningkatkan kualitas hidup wisatawan dan masyarakat lokal (Utama, 2011). Meningkatnya kunjungan wisatawan dan meningkatnya pendapatan yang dihasilkan oleh subsektor perdagangan, hotel, dan restoran berpengaruh terhadap peningkatan PDRB dan penyerapan tenaga kerja (Utama, 2006). Oleh karena itu, peran tenaga kerja di bidang pariwisata juga berperan penting di dalam sektor pariwisata (Utama, 2011; Ningsih dan Suryasih: 2018).

Adapun dalam mempermudah penelitian ini maka dibuat kerangka pikir yang dapat digambarkan sebagai berikut:

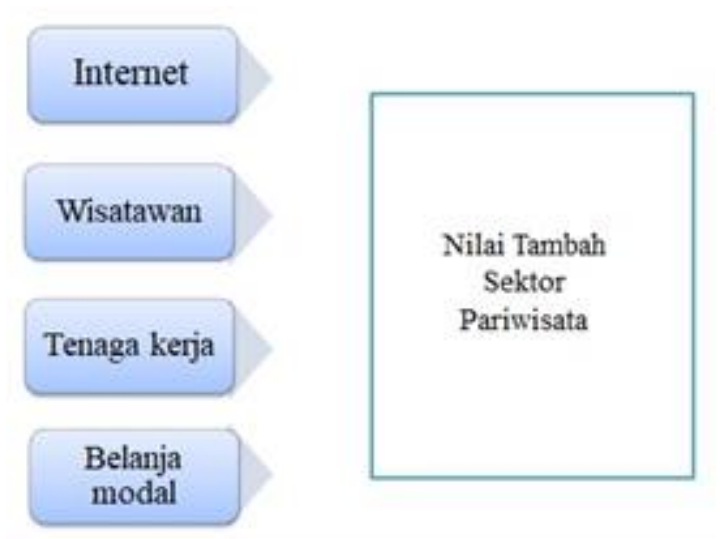

Gambar 1. Kerangka pikir penelitian 
Adanya persentase pengguna internet yang berbanding lurus maupun tidak berbanding lurus dengan nilai tambah sektor pariwisata menyebabkan adanya indikasi perbedaan pengaruh TIK terhadap nilai tambah sektor pariwisata pada setiap kabupaten atau kota di Provinsi Jawa Tengah. Selain itu, sektor pariwisata merupakan komponen yang menjadi kontribusi di dalam pertumbuhan ekonomi sehingga perlu diketahui bagaimana peningkatan TIK, salah satunya pengguna internet terhadap pertumbuhan ekonomi yang dilihat dari sektor pariwisata. Oleh karena itu, dilakukan penelitian untuk memberikan gambaran kondisi sektor pariwisata dan persentase pengguna internet di Jawa Tengah dan mengetahui pengaruh TIK terhadap peningkatan nilai tambah sektor pariwisata di Jawa Tengah tahun 2015-2018.

\section{METODE PENELITIAN}

\section{Sumber Data dan Variabel Operasional}

Penelitian ini menggunakan data sekunder yang bersumber dari Badan Pusat Statistik (BPS) dengan cakupan 35 kabupaten atau kota di Provinsi Jawa Tengah dan Dinas Kepemudaan, Olahraga, dan Pariwisata (Disporapar) Jawa Tengah. Variabel nilai tambah sektor pariwisata yang dimaksud dalam penelitian ini adalah sektor penyediaan akomodasi dan makan minum yang terdapat di dalam PDRB kabupaten atau kota Provinsi Jawa Tengah. Kemudian, variabel-variabel yang digunakan di penelitian ini akan dijelaskan ringkas pada Tabel 2.

Adapun variabel-variabel yang diduga memengaruhi peningkatan nilai tambah sektor pariwisata yaitu pengguna internet, jumlah wisatawan, jumlah tenaga kerja, dan belanja modal.

Tabel 2.

Variabel Penelitian

\begin{tabular}{ll}
\hline \multicolumn{1}{c}{ Variabel } & \multicolumn{2}{c}{ Penjelasan } \\
\hline $\begin{array}{l}\text { Sektor } \\
\text { pariwisata }\end{array}$ & $\begin{array}{l}\text { Sektor yang diproksikan oleh nilai tambah sektor penyediaan akomodasi } \\
\text { dan makan minum. Sektor yang mencakup penyediaan akomodasi } \\
\text { penginapan jangka pendek bagi pengunjung serta pelancong lainnya dan } \\
\text { penyediaan makanan dan minuman untuk jenis konsumsi segera }\end{array}$ \\
Internet & $\begin{array}{l}\text { Persentase pengguna internet di kabupaten atau kota } \\
\text { Wisatawan }\end{array}$ \\
Jumlah wisatawan nusantara \\
dan mancanegara
\end{tabular}

\section{Metode Analisis}

Metode analisis yang digunakan di dalam penelitian ini menggunakan analisis deskriptif dan inferensia. Analisis deskriptif yang digunakan untuk melihat kondisi data berupa peta tematik, diagram, dan grafik yang digunakan untuk menggambarkan secara umum jumlah pengguna internet di kabupaten atau kota di Provinsi Jawa Tengah serta variabel-variabel lain yang 
memengaruhi nilai tambah sektor pariwisata.

Sementara itu, analisis inferensia digunakan untuk mengetahui faktor-faktor apa saja yang berpengaruh dalam peningkatan sektor pariwisata di Provinsi Jawa Tengah.

Dalam penelitian ini, penulis menggunakan model regresi data panel. Data panel adalah penyatuan antara data lintas waktu (time series) dan data lintas individu (cross section) (Ekananda, 2016). Data lintas waktu dan individu dalam penelitian ini meliputi penelitian yang menggunakan tahun 2015 hingga 2018 dengan cakupan 35 kabupaten atau kota Provinsi Jawa Tengah. Adapun model penelitian persamaan regresi panel dalam penelitian ini adalah sebagai berikut:

$$
\begin{aligned}
& \text { InPariwisata }_{i t}=a+\beta_{1} \text { Internet }_{i t}+ \\
& \beta_{2} \ln \text { Wisatawan }_{i t}+ \\
& \beta_{3} \ln T K_{i t}+\beta_{4} \ln B M_{i t}+ \\
& U_{i t}
\end{aligned}
$$

Keterangan:

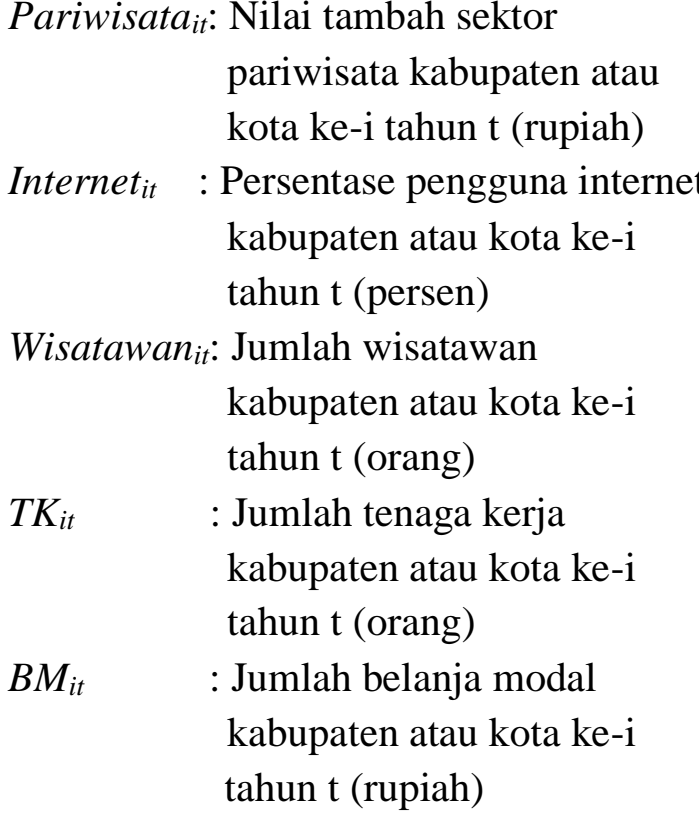

i

$\mathrm{t}$

$: 1,2,3, \ldots, \mathrm{N}$ individu/

kabupaten atau kota dalam penelitian

$: 1,2,3, \ldots, \mathrm{T}$ periode dalam

penelitian

Pariwisata $_{i t}$ Nilai tambah sektor pariwisata kabupaten atau
Adapun tahapan-tahapan regresi data panel yang dilakukan di dalam penelitian ini adalah sebagai berikut:

1. Pembentukan model regresi data panel

Langkah pertama yaitu meregresikan data panel dengan melibatkan variabel bebas dengan variabel terikat.

2. Menguji ada tidaknya efek individual dan waktu

Pada pengujian ini dilakukan untuk mengetahui apakah model regresi panel memiliki efek individual dan waktu melalui Lagrange multiplier tests. Jika model regresi panel hanya memiliki salah satu efek maka jenis regresi panel yang digunakan adalah one way sedangkan apabila memenuhi kedua efek maka regresi panel yang digunakan adalah two ways.

3. Pemilihan model regresi data panel terbaik

Pemilihan model regresi panel terbaik dilakukan melalui beberapa uji seperti uji Chow, uji Hausman, dan uji BP-LM. Uji Chow dilakukan untuk memilih model terbaik antara Common Effect Model (CEM) dan Fixed Effect Model (FEM). Uji Hausman dilakukan untuk memilih model terbaik antara Random Effect Model dan Fixed Effect Model (FEM). Uji BP-LM dilakukan untuk memilih model terbaik antara Common Effect Model (CEM) dan Random Effect Model (REM).

4. Menentukan metode estimasi

Sebelum menentukan metode estimasi, apabila model regresi panel terbaik yang terpilih adalah Common Effect Model (CEM) dan Fixed Effect Model (FEM) maka dilakukan pengujian struktur varians-kovarians residual. Pengujian ini dilakukan untuk mengetahui residual bersifat 
homoskedastisitas

heteroskedastisitas.

Apabila residual

heteroskedastisitas maka dilakukan

Likelihood Ratio ( $\lambda \mathrm{LR}$ test). Pengujian ini dilakukan untuk mengetahui ada tidaknya cross sectional correlation dari struktur varians kovarians yang bersifat heteroskedastisitas. Berdasarkan kedua pengujian tersebut maka terdapat tiga jenis metode estimasi yang digunakan pada model regresi panel terbaik yang terpilih Common Effect Model (CEM) dan Fixed Effect Model (FEM), yaitu OLS, GLS, FGLS dengan Seemingly Unrelated Regression (SUR). Lain halnya apabila model regresi panel terbaik yang terpilih adalah Random Effect Model (REM) maka metode estimasi yang digunakan adalah GLS.

5. Melakukan pengujian asumsi klasik

6. Melakukan pengujian keberartian model

7. Interpretasi terhadap model regresi data panel terpilih

\section{HASIL DAN PEMBAHASAN}

\section{Gambaran Umum Perkembangan Sektor} Pariwisata dan TIK

Sektor pariwisata merupakan salah satu sektor yang penting dalam mendukung perekonomian di Indonesia. Hal tersebut juga didukung dengan adanya peningkatan pembangunan infrastruktur di berbagai wilayah sehingga sektor pariwisata diproyeksikan akan dimungkinkan menjadi penyumbang devisa terbesar dan core economy di Indonesia. Bahkan saat ini sektor pariwisata ditetapkan sebagai sektor unggulan yang turut berperan di perekonomian Indonesia melampaui $\mathrm{CPO}$ (minyak sawit mentah) (kemenpar.go.id).

Provinsi Jawa Tengah merupakan salah satu provinsi yang menjadi tujuan berwisata oleh wisatawan karena provinsi tersebut memiliki potensi pariwisata yang besar serta setiap kabupaten atau kota memiliki tempat wisata yang berbeda-beda. Berdasarkan Gambar 1 pada tahun 2015, jumlah wisatawan tertinggi berada di Kabupaten Magelang sedangkan jumlah wisatawan terendah berada di Kabupaten Cilacap. Pada tahun 2018, jumlah wisatawan tertinggi berada di Kota Semarang sedangkan jumlah wisatawan terendah berada di Kabupaten Sukoharjo.

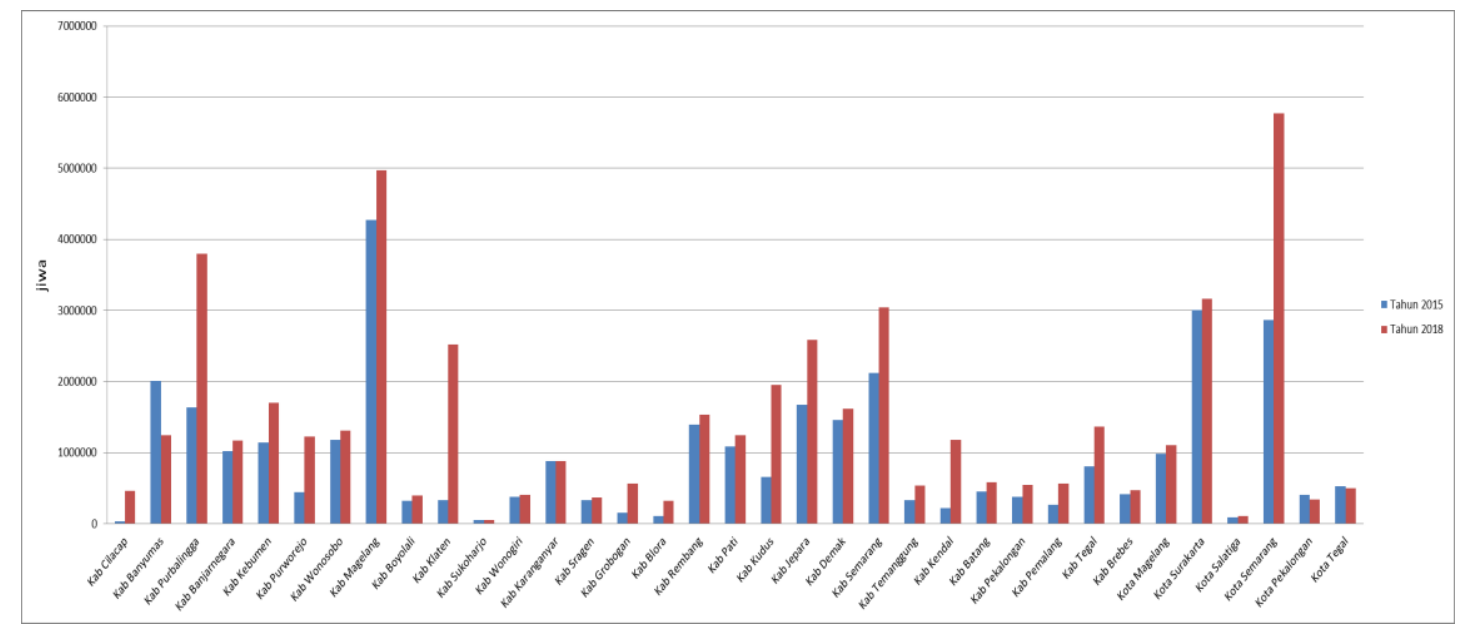

Gambar 2.

Jumlah wisatawan di Provinsi Jawa Tengah tahun 2015 dan 2018 Sumber: Badan Pusat Statistik, 2015 dan 2018 (diolah) 

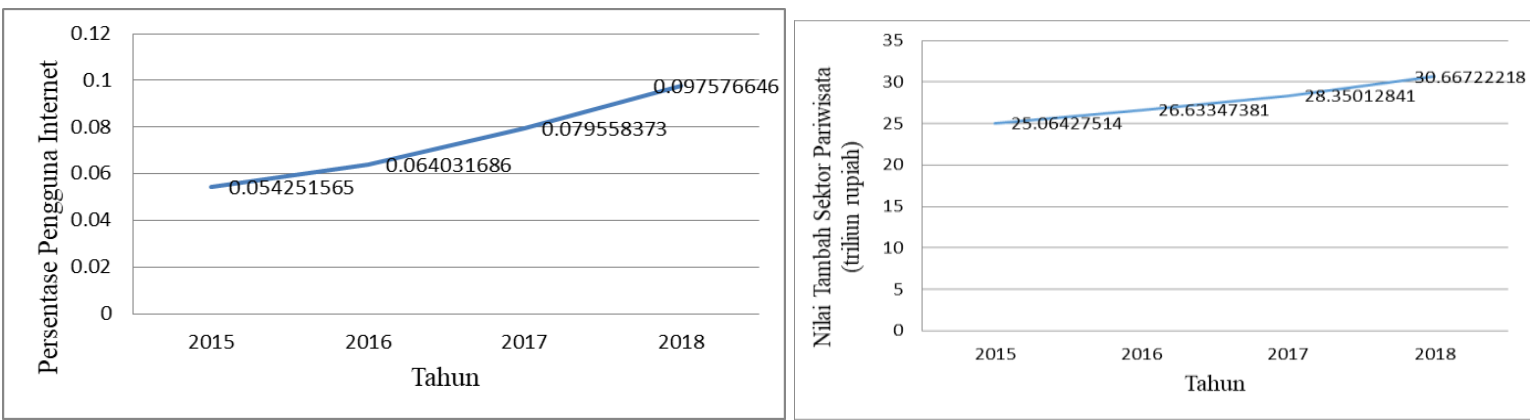

Grafik 1.

Perkembangan persentase pengguna internet dan nilai tambah sektor pariwisata di Jawa

Tengah tahun 2015-2018

Sumber: Badan Pusat Statistik (diolah)

Adanya wisatawan yang mengunjungi tempat wisata tidak terlepas dari informasi. Melalui penggunaan TIK salah satunya adalah internet, wisatawan dapat memperoleh informasi mengenai tempattempat wisata, akomodasi, serta jasa-jasa lainnya yang berkaitan dengan pariwisata. Berdasarkan Grafik 1 persentase pengguna internet di Jawa Tengah terus mengalami peningkatan dari tahun 2015 hingga 2018.
Hal ini menunjukkan internet telah memiliki peranan yang penting di kalangan wisatawan. Akibat adanya peran internet di kalangan wisatawan, dapat mendukung meningkatkan nilai tambah sektor pariwisata yang diproksikan dengan sektor penyediaan akomodasi dan makan minum. Hal ini terbukti bahwa pada tahun 2015 hingga 2018 nilai tambah sektor pariwisata selalu mengalami peningkatan.
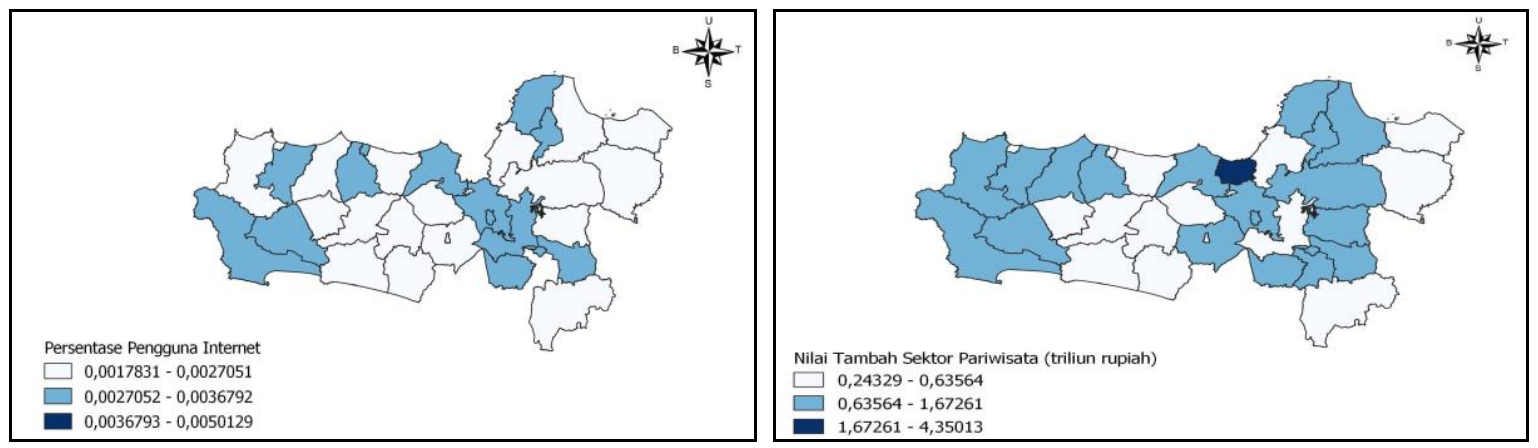

Gambar 3.

Peta Tematik persentase pengguna internet dan nilai tambah sektor pariwisata di Jawa Tengah tahun 2018

Sumber: Badan Pusat Statistik, 2018 (diolah)

Meskipun persentase pengguna internet dan nilai tambah sektor pariwisata terus mengalami peningkatan, namun tidak diiringi dengan pemerataan di kabupaten atau kota Provinsi Jawa Tengah. Hal ini terdapat pada Gambar 3.

Wilayah yang berwarna biru gelap pada peta tematik persentase pengguna internet menunjukkan wilayah tersebut memiliki persentase pengguna internet yang tinggi sedangkan wilayah yang berwarna biru terang menunjukkan wilayah tersebut memiliki persentase pengguna internet yang rendah. Begitu pula dengan peta tematik nilai tambah sektor pariwisata. Wilayah yang berwarna biru gelap menunjukkan 
wilayah tersebut memiliki nilai tambah sektor pariwisata yang tinggi sedangkan wilayah yang berwarna biru terang menunjukkan wilayah tersebut memiliki nilai tambah sektor pariwisata yang rendah.
Terdapat wilayah yang memiliki persentase pengguna internet tinggi namun memiliki nilai tambah sektor pariwisata rendah, misalnya Kabupaten Sukoharjo, Kabupaten Karanganyar, dan Kabupaten Kudus.

Tabel 3.

Tabel Diagnosis Regresi Data Panel

\begin{tabular}{|c|c|c|c|c|}
\hline Diagnosis & Hipotesis nol & Hasil & \multicolumn{2}{|c|}{ Kesimpulan } \\
\hline $\begin{array}{l}\text { Lagrange multiplier } \\
\text { test untuk efek } \\
\text { individual }\end{array}$ & $\begin{array}{l}\text { Tidak terdapat efek } \\
\text { individu }\end{array}$ & $p$-value $<2.2 \mathrm{e}-16$ & $\begin{array}{l}\text { Terdapat } \\
\text { individu }\end{array}$ & efek \\
\hline $\begin{array}{l}\text { Lagrange multiplier } \\
\text { test untuk efek } \\
\text { waktu }\end{array}$ & $\begin{array}{l}\text { Tidak terdapat efek } \\
\text { waktu }\end{array}$ & $p$-value $=0.7804$ & $\begin{array}{l}\text { Tidak } \\
\text { efek wak }\end{array}$ & $\begin{array}{l}\text { terdapat } \\
\text { tu }\end{array}$ \\
\hline Chow test & $\begin{array}{l}\text { Common Effect } \\
\text { Model (CEM) lebih } \\
\text { baik daripada Fixed } \\
\text { Effect Model (FEM) }\end{array}$ & $p$-value $<2.2 \mathrm{e}-16$ & $\begin{array}{l}\text { Fixed } \\
\text { Model } \\
\text { lebih } \\
\text { daripada } \\
\text { Effect } \\
\text { (CEM) }\end{array}$ & $\begin{array}{r}\text { Effect } \\
\text { (FEM) } \\
\text { baik } \\
\text { Common } \\
\text { Model }\end{array}$ \\
\hline Hausman test & $\begin{array}{l}\text { Random Effect } \\
\text { Model (REM) lebih } \\
\text { baik daripada Fixed } \\
\text { Effect Model (FEM) }\end{array}$ & $p$-value $=0.0776$ & $\begin{array}{l}\text { Random } \\
\text { Model } \\
\text { lebih } \\
\text { daripada } \\
\text { Effect } \\
\text { (FEM) }\end{array}$ & $\begin{array}{r}\text { Effect } \\
\text { (REM) } \\
\text { baik } \\
\text { Fixed } \\
\text { Model }\end{array}$ \\
\hline $\begin{array}{l}\text { Breusch-Pagan } \\
\text { Heteroscedasticity } \\
\text { Test of Random } \\
\text { Effect }\end{array}$ & Homoskedastisitas & $p$-value $=0.1378$ & Homoske & dastisitas \\
\hline
\end{tabular}

\section{Estimasi Model Regresi Data Panel}

Sebelum dilakukan estimasi model regresi data panel, maka dilakukan beberapa tahapan pengujian yang disajikan dalam Tabel 3. Berdasarkan Tabel 3 setelah dilakukan beberapa pengujian maka diperoleh model terbaik yaitu One Way Random Effect Model (REM). Adapun hasil estimasi model regresi data panel dengan menggunakan model terbaik disajikan pada Tabel 4. Pada tabel tersebut menunjukkan bahwa sebagian besar variabel yang terlibat dalam estimasi model menunjukkan hasil yang signifikan secara statistik pada tingkat signifikansi 5 persen. Kemudian tanda pada estimasi koefisien regresi data panel secara umum sesuai dengan apa yang diharapkan. 
Tabel 4.

Estimasi persamaan regresi data panel

\begin{tabular}{lrrrr}
\hline & Estimate & Std. Error & z-value & $\operatorname{Pr}(>|\mathrm{z}|)$ \\
\hline (Intersep) & 25,7385 & 0,3989 & 64,5095 & $<2,2 \mathrm{e}-16^{* * *}$ \\
Internet & 1,5923 & 0,1824 & 8,7290 & $<2.2 \mathrm{e}-16^{* * *}$ \\
Wisatawan & 0,0202 & 0,0158 & 1,2762 & 0,2018 \\
TK & 0,0399 & 0,0142 & 2.8130 & $0,0049 * *$ \\
BM & 0,0419 & 0,0182 & 2.3027 & $0,0213 *$ \\
\hline
\end{tabular}

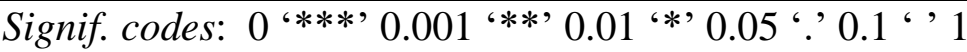

R-Squared: $\quad 0.53573$

Adj. R-Squared: 0.52197

Berdasarkan Tabel 4 menunjukkan bahwa persentase pengguna internet, jumlah tenaga kerja, dan belanja modal memiliki pengaruh yang signifikan terhadap sektor pariwisata. Hubungan ini dapat dibentuk persamaan sebagai berikut: InPariwisata $_{i t}=25,7385+$

$$
\begin{aligned}
& \text { 1,5923Internet }{ }_{i t}+ \\
& 0,0202 \ln \text { Wisatawan }_{i t} \\
& +0,0399 \ln T K_{i t}+ \\
& 0,0419 \ln B M_{i t}
\end{aligned}
$$

Adj. $\quad R$-Squared menunjukkan nilai sebesar 52,2\%. Hal ini maksudnya adalah pengguna internet, jumlah wisatawan, jumlah tenaga kerja, belanja modal mampu menjelaskan nilai tambah sektor pariwisata sebesar 52,2\% dan sisanya dijelaskan oleh variabel lain yang tidak terlibat di dalam model penelitian.

\section{Pengaruh Pengguna Internet dan Faktor Lain terhadap Nilai Tambah Sektor Pariwisata}

Berdasarkan Tabel 4, apabila dilihat secara parsial persentase pengguna internet berpengaruh positif dan signifikan terhadap nilai tambah sektor pariwisata. Oleh karena itu, dapat diketahui bahwa persentase pengguna internet merupakan salah satu faktor yang penting dalam mendukung sektor pariwisata di Provinsi Jawa Tengah.
Apabila terjadi peningkatan sebesar $1 \%$ pengguna internet maka akan meningkatkan nilai tambah sektor pariwisata sebesar $1,59 \%$. Adannya penggunaan internet di kalangan wisatawan dapat mempermudah wisatawan dalam memperoleh informasi secara cepat yang berkaitan dengan pariwisata. Informasi yang diperoleh tersebut dapat mengenai tempat wisata, penginapan, rumah makan, tempat membeli cindera mata, dan lain-lain.

Tempat wisata merupakan salah satu hal yang dijadikan informasi utama oleh wisatawan sebelum berwisata. Biasanya di situs-situs tertentu terdapat infomasi mengenai lokasi, waktu dibukanya tempat wisata, tiket masuk, dan hal-hal yang menarik yang terdapat di tempat wisata tersebut.

Dalam mempermudah wisatawan untuk menginap di sekitar tempat wisata, biasanya terdapat beberapa penginapan dengan berbagai macam harga. Apalagi didukung dengan berbagai macam aplikasi yang dapat melakukan booking terhadap sejumlah kamar di penginapan.

Tidak hanya dalam hal penginapan saja yang diperlukan wisatawan. Wisatawan juga memerlukan alat transportasi untuk pergi ke tempat wisata. Apabila tempat wisata jauh dari daerah tempat tinggal, 
wisatawan dapat melakukan pemesanan tiket transportasi umum seperti kereta api dan pesawat secara online. Hal ini mempermudah wisatawan sehingga tidak memerlukan waktu yang lama dan tenaga yang lebih.

Namun, lain halnya dengan jumlah wisatawan. Variabel ini berpengaruh positif dan tidak signifikan terhadap nilai tambah sektor pariwisata. Jadi variabel yang memberikan pengaruh paling besar dan signifikan adalah persentase pengguna internet. Hal ini dikarenakan berdasarkan data Badan Pusat Statistik (BPS) pada tahun 2015-2017 perkembangan subindeks penggunaan yang dijadikan salah satu penyusun IP-TIK terus mengalami peningkatan, salah satunya didukung oleh jumlah pengguna internet. Pada tahun 2017 subindeks penggunaan di Provinsi Jawa Tengah sebesar 4,19. Angka tersebut meningkat dibandingkan tahun sebelumnya yang hanya sebesar 2,95. Kemudian pada tahun sebelumnya lagi hanya sebesar 1,98.

Faktor tenaga kerja tidak kalah penting dalam berperan di sektor pariwisata. Berdasarkan Tabel 4, apabila dilihat secara parsial jumlah tenaga kerja berpengaruh positif dan signifikan terhadap nilai tambah sektor pariwisata. Apabila terjadi peningkatan $1 \%$ jumlah tenaga kerja di usaha pariwisata maka akan meningkatkan nilai tambah sektor pariwisata sebesar $0,04 \%$. Adanya usaha-usaha yang berkaitan dengan pariwisata sehingga membuka kesempatan kerja bagi masyarakat, khususnya masyarakat sekitar. Hal ini juga akan mengurangi jumlah pengangguran serta meningkatkan kualitas hidup masyarakat. Adanya pembangunan usaha pariwisata, selain untuk memperoleh pendapatan daerah akan tetapi efektif juga untuk mengurangi jumlah pengangguran.
Perkembangan sektor pariwisata tidak terlepas dari peran pemerintah. Salah satunya pemerintah berperan dalam mengalokasikan pengeluaran untuk keperluan belanja modal. Berdasarkan Tabel 4, apabila dilihat secara parsial belanja modal berpengaruh positif dan signifikan terhadap nilai tambah sektor pariwisata. Apabila terjadi peningkatan $1 \%$ belanja modal maka akan meningkatkan nilai tambah sektor pariwisata sebesar 0,04\%. Alokasi dana untuk belanja modal dapat digunakan untuk pembelian atau pembangunan aset tetap yang berwujud yang memiliki nilai manfaat yang lebih dari satu tahun. Pembentukan aset tersebut misalnya meliputi pengadaan tanah, alatalat komunikasi, penerangan jalan, instalasi listrik dan telepon, konstruksi jalan, jembatan, dan lain-lain. Tanpa adanya asetaset tersebut nantinya akan menghambat nilai tambah sektor pariwisata.

Adanya perbedaan persentase pengguna internet, jumlah tenaga kerja di usaha pariwisata, dan kebijakan daerah dalam mengalokasikasikan belanja modal dapat menyebabkan terjadinya perbedaan nilai tambah sektor pariwisata di kabupaten atau kota di Jawa Tengah. Adanya jumlah yang banyak dari persentase pengguna internet, jumlah tenaga kerja di usaha pariwisata, dan belanja modal dapat menghasilkan nilai tambah sektor pariwisata yang besar.

\section{SIMPULAN}

Pada tahun 2015 hingga 2018 persentase pengguna Internet di Provinsi Jawa Tengah terus mengalami peningkatan. Namun, pertumbuhan tersebut tidak diiringi dengan pemerataan persentase pengguna internet di kabupaten atau kota Provinsi Jawa Tengah. Oleh karena itu, terjadilah kesenjangan digital di antara kabupaten atau kota di provinsi tersebut. Pada tahun 2018 Kota 
Semarang memiliki persentase pengguna internet tertinggi sedangkan Kabupaten Blora memiliki persentase pengguna internet terendah. Akan tetapi berdasarkan hasil penelitian peringkat persentase pengguna internet tidak selamanya berbanding lurus dengan peringkat nilai tambah sektor pariwisata yang dimiliki kabupaten atau kota. Penelitian ini menyimpulkan bahwa persentase pengguna internet, jumlah tenaga kerja usaha pariwisata, dan belanja modal berpengaruh positif dan signifikan terhadap nilai tambah sektor pariwisata. Oleh karena itu, peningkatan nilai tambah sektor pariwisata perlu ditunjang oleh peningkatan promosi melalui internet. Selain itu, diperlukan peran Pemerintah dalam mengalokasikan modal untuk perkembangan sektor pariwisata.

\section{DAFTAR PUSTAKA}

Baloglu, S., \& McCleary, K. W. (1999). A Model of Destination Image Formation. Annals of Tourism Research, 26(4), 868-897.

Bekteshi, Luan dan Jonida Bekteshi. (2017). Use of ICT and Develepoment of Tourism Sector in Albania. European Scientific Journal September 2017 edition Vol.13, No.25.

Echtner, C. M. \& Ritchie, J. R. B.. (1991). The Meaning and Measurement of Destination Image. Journal of Tourism Studies, 2(2), 2-12.

Ekananda, Mahyus. (2016). Analisis Ekonometrika Data Panel : Teori Lengkap dan Pembahasan Menyeluruh Bagi Penelitian Ekonomi, Bisnis, dan Sosial Edisi 2. Jakarta : Mitra Wacana Media.

Ilić, Ivana dan Anđelija Nikolić. (2018). Implications of Modern Technology Development for The Tourism Sector of The Republic of Serbia. ЕКОНОМИКА Vol. 64, januarymarch 2018, № 1 .

Jonathan, Claresta Janice dan Riswan Efendi Tarigan. (2016). The Effects of E-Tourism to The Development of Tourism Sector In Indonesia. CommIT (Communication \& Information Technology) Journal 10(2).

Kementerian Pariwisata. (2015). Rencana Strategis 2015-2019 Kementerian Pariwisata. Diakses dari https://www.kemenpar.go.id/post/rencana-strategis-2015-2019kementerian-pariwisata Tanggal 19 Februari 2020.

Kementerian Pariwisata. (2020). Data Kunjungan Wisatawan Mancanegara Bulanan Tahun 2019. Diakses dari https://www.kemenpar.go.id/post/data-kunjungan-wisatawanmancanegara-bulanan-tahun-2019 Tanggal 19 Februari 2020.

Kementerian Pariwisata. (2020). Siaran Pers : Pariwisata Diproyeksikan Jadi Penyumbang Devisa Terbesar Lima Tahun ke Depan. Diakses dari https://www.kemenpar.go.id/post/siaran-pers-pariwisata-diproyeksikan-jadipenyumbang-devisa-terbesar-lima-tahun-ke-depan Tanggal 19 Februari 2020. 
Mankiw, N. Gregory. (2010). Macroeconomics Seventh Edition. New York: Worth Publishers.

Mihalic, Tanja dan Dimitrios Buhalis. (2013). ICT As A New Competitive Advantage Factor-Case Of Small Transitional Hotel Sector. Economic and Business Review Vol 15 No.1 Maret 2013. 33-56.

Ningsih, Ni Wayan Ariyoshi Sastra dan Ida Ayu Suryasih. (2018). Dampak Sosial Ekonomi Pariwisata terhadap Pedagang Souvenir di Daya Tarik Wisata Pura Gunung Kawi Tampaksiring Gianyar. Jurnal Destinasi Pariwisata Vol. 6 No 1.

Pemerintah Provinsi Jawa Tengah. (2019). Jateng Sabet Penghargaan Destinasi Wisata Halal Unggulan. Diakses dari https://jatengprov.go.id/beritaopd/jateng-sabetpenghargaan-destinasi-wisata-halal-unggulan/ Tanggal 19 Februari 2020.

Susanta, Jaka. (2016). Pengaruh Teknologi Informasi dan Komunikasi terhadap Strategi Pengembangan Pariwisata Yogyakarta. Diakses dari http://etd.repository.ugm.ac.id/.

Syarifah, Fitri. (2016). Jawa Tengah Sabet Penghargaan Indonesia's Attractiveness Award 2019. Diakses dari https://www.liputan6.com/lifestyle/read/4021823/jawa-tengahsabet-penghargaan-indonesias-attractiveness-award-2019 Tanggal 19 Februari 2020

Todaro, Michael P. Todaro dan Stephen C. Smith. (2003). Pembangunan Ekonomi di Dunia Ketiga Jilid 1 Edisi Kedelapan. Jakarta: Erlangga.

Utama, Made Suryana. (2006). Pengaruh Perkembangan Pariwisata terhadap Kinerja Perekonomian dan Perubahan Struktur Ekonomi serta Kesejahteraan Masyarakat di Provinsi Bali. Disertasi thesis, Universitas Airlangga.

Utama, I Gusti Bagus Rai. (2011). Dimensi Ekonomi Pariwisata Kajian Dampak Ekonomi dan Keunggulan Pariwisata Kabupaten/Kota di Provinsi Bali. Diakses dari https://www.researchgate.net/publication/274644432 Tanggal 3 April 2020.

World Travel \& Tourism Council. (2018). Travel \& Tourism Economic Impact 2018 World. London: World Travel \& Tourism Council.

Zhang, H., Fu, X., Cai, L. A., \& Lu, L. (2014). Destination image and tourist loyalty: A meta-analysis. Tourism Management, 40, 213-223. 